\begin{tabular}{ll}
\hline コンクリートポンプエ法に & REDUCTION OF PRELIMINARY \\
おける先送り王ルタ多の低 & MORTAR IN THE CONCRETE \\
減に関する実験的研究 & PUMPING PRACTICE \\
\hline
\end{tabular}

毛見虎雄 $-* 1$
中田善久 $* 2$
長尾信夫 $-* 3$
小池 茂 $-* 4$
藤井和俊 $-* 5$
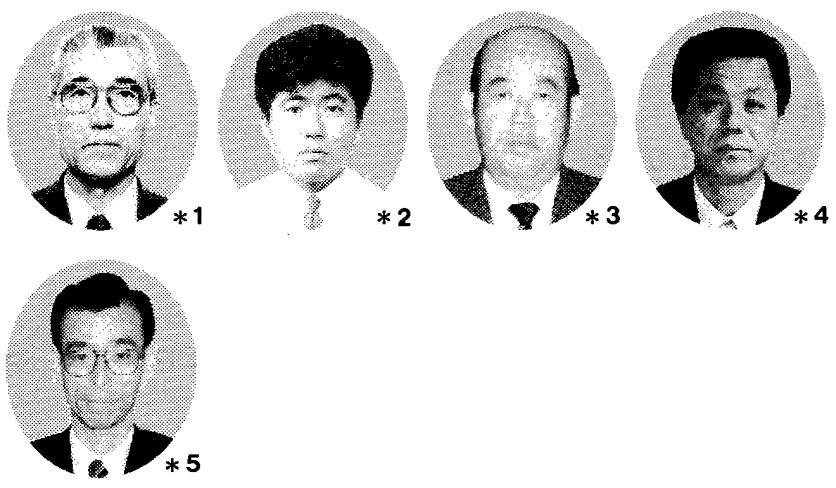

キーワード :

コンクリートポンプエ法, 先送りモルタル, ポンパビリティー, 压送コンクリート の品質, アンケート, 低減

\section{Torao KEMI \\ Yoshihisa NAKaTA \\ Nobuo NAGAO \\ Shigeru KOIKE \\ Kazutoshi FUJII}

The preliminary mortar pumping has been recommended so as to assure lubrication between pipes and concrete slurry. However, technical parameters for the mortar actually employed in practice have not been surveyed so far. Research on the state-of-the art of the preliminary mortar pumping was made on the basis of 267 respondents over the country in addition to our own experiments. As a result, method, material and amount of the preliminary mortar pumping were reexamined, and the possible means to reduce it is presented.

\section{1 はじめに}

近年，コンクリートポンプ工法は，建築現場において汎用工法の 一つとなっている。この中のコンクリートポンプは, 1965 年頃から 建築現場に登場し，今ではこの圧送方式も配管からブーム式に変わ り, そのブーム長さも 29〜 $32 \mathrm{~m}$ クラスが主流となっている。この背 景には，コンクリートポンプの高圧化，大容量化抢よび機動性など の能力向上が一つの技術進歩1)としてあげられる。また，もう一つの 技術進歩として，圧送するコンクリートの調合上の配虑，圧送前後 におけるコンクリートの品質, 圧力損失の究明, 型枠の補強および 圧送施工技能士のレベルアップ等が現場施工の経緯の中で向上して きたためである。これより, 日本建築学会では 1994 年に「コンクリ ートポンプ工法施工指針・同解説」2)（以下，施工指針という）が改 訂された。しかし，この中で先送りモルタルは，コンクリートの圧 送に先立ち, 水およびモルタルを圧送するように定められているが, この先送りモルタルの必要性は森永らの実証実験 ${ }^{3)}$ のに過ぎず, 構造体コンクリートへの打設および処理については実務上の問題が 残されている。

そこで, 本研究は, コンクリートポンプ工法に扔ける圧送開始時
Keywords :

The concrete pumping practice, Preliminary mortar, Pumpability, Quality of concrete pumping, Questionnaire, Reduction

\footnotetext{
${ }^{* 1}$ 足利工業大学工学部建築学科 教授・工博

*2 西松建設技術研究所 研究員・工修

${ }^{* 3}$ 日本コンクリート工事 代表取締役（全国コンクリート圧送事業団体連合会 技術委員長)

*4 木暮産業 代表取締役（全国コンクリート圧送事業団体連合会技術副委員長）

${ }^{* 5}$ 三菱建設技術研究所 副所長

*I Prof., Dept. of Architecture, Faculty of Engineering, Ashikaga Institute of Technology, Dr. Eng.

*2 Research Engineer, Technical Research Institute, Nisimatsu Construction Co., LTD., M. Eng.

${ }^{* 3}$ Nihon Concrete Construction Co., LTD

*4 Kogure Industry Co., LTD

*5 Assistant Director, Technical Research Institute, Mitsubishi Construction Co., LTD.
}

のポンプ圧送性を向上させ，さらにコンクリートの品質を低下させ ずに資源の節約およびリサイクルの観点から先送りモルタルを低減 させるため, 先送りモルタルの実態調査を行い, セメントを主とし た先送り材の種類・量および圧送方法について実験検討を行った。

本報告は, これまでに報告(4) 8) したものに加筆検討してとりまと めたものである。

\title{
2「コンクリートポンプ工法施工指針・同解説 $\rfloor^{2)}$ 中 における先送りモルタルと本研究との関係
}

施工指針中では，先送りモルタルを閉塞防止のために「コンクリ 一トの圧送開始に先立ち，ポンプおよび配管の内面の潤滑性保持の ために，水抢よびモルタルを圧送する。ように定められ，クリーナ ボールなどの詰物を用いて水を封入した後でモルタルを圧送し，水 拉よびモルタルが管内に十分充填されるようにして圧送するように 解説されている。また，この水およびモルタルの圧送方法は，一つ の例としてピンバルル穴から給水し, モルタルはホッパーへ投入す るように解説されている。この先送りモルタルの調合および必要量 は，圧送するコンクリートの調合および配管の径ならびに長さによ り定め, 先送りされた健全なモルタルは, 薄い層になるように広い 
範囲に分散させて打ち込むように解説されている。この他に，水扔 よびモルタルの先送りを行わないで，コンクリートをじかに圧送で きる距離は $10 \mathrm{~m}$ 程度とされている。この先送りモルタルの必要量 は, 配管の内面積 $1 \mathrm{~m}^{2}$ 当り $0.75 \ell$ とし, ゴムパッキング部に充填さ れる量も含めて,この量の 3 倍程度の配管の内面積 $1 \mathrm{~m}^{2}$ 当り 2.25 $\ell$ と経験的にされている。

本研究は,このように経験的なデータから定められた施工指針中 の先送りモルタルの必要量を先送り材の種類ならびに圧送方法の面 からコンクリートの品質, 資源の節約抢よびリサイクルの観点を踏 まえ,この量を低減させるために行ったものである。

\section{3 先送りモルタルの使用状況に関する実態調査}

\section{(1) 調査概要}

コンクリートポンプ工法における先送りモルタルの使用状況の実 態を把握するため ( a ) 全国コンクリート圧送事業団体連合会に所 属している圧送施工技能士ならびに ( b ) ゼネコン 17 社の現場経験 者を対象にアンケート調査を行った。このアンケートの内容は, 先 送りモルタルの使用状況ならびに使用理由, 先送りモルタルの調 合・量および圧送方法などについて行った。

(2) 調査結果

アンケート調査の回答は，(a ) 全国コンクリート圧送事業団体連 合会において 1 都 30 県から 98 件の回答があり, また，（b ) ゼネコ ンにおいて全国的な現場から 140 件と技術関係から 127 件の合計 267 件の回答があった。このアンケート調査結果概要を図 1 に示す。

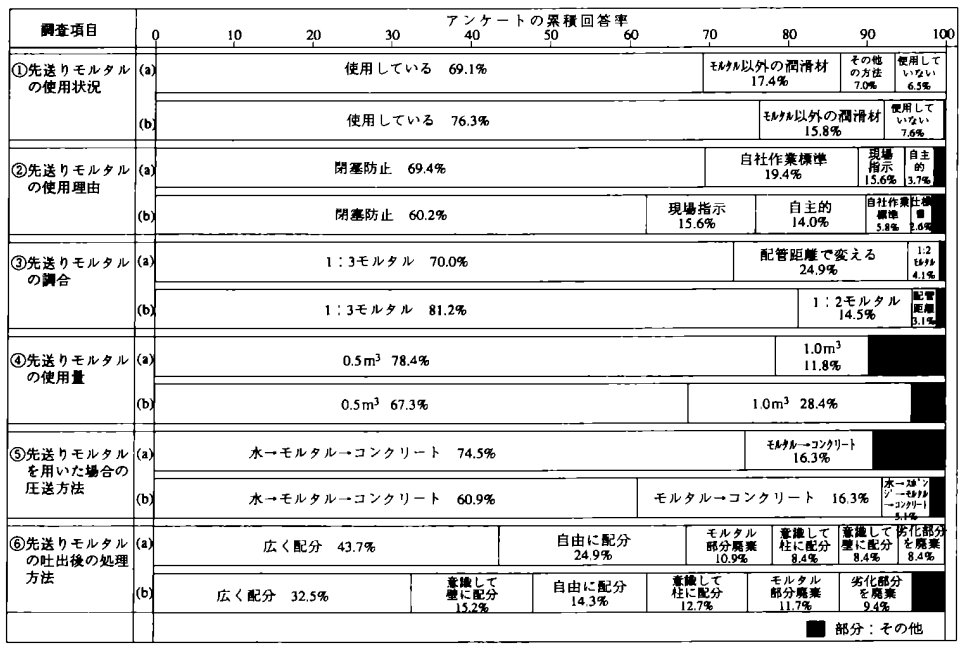

図1 アンケート調查結果概要

アンケートの結果は，(a ) 全国コンクリート圧送事業団体連合の場 合と ( b ) ゼネコンの場合とでは, 結果が若干異なるが総括的に「(1) 先送りモルタルは, 使用されている場合が多く, (2)その理由は, 閉 塞防止のため行われ, (3)その調合は, $1: 3$ モルタルであり, (4)この

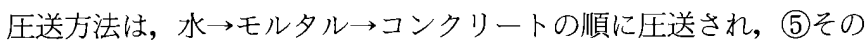
使用量は, $0.5 \mathrm{~m}^{3}$ で，6広く配分されて打込まれている。という回 答が多かった。この中で, 先送りモルタルの使用量が $0.5 \mathrm{~m}^{3}$ および $1.0 \mathrm{~m}^{3}$ という回答が多かった理由として, 生コン工場が製造・納品 する量がこの量であると考えられる。また，施工指針と異なり，ク リーナボールが使用されていないことや柱に打ち込まれている場合
もある。この構造部材への打ち込みは, 廃棄物にしたくないという 処理の問題とこの使用量の問題が大きな原因と考えられる。

\section{4 先送りモルタルの低減に関する圧送実験}

\section{（1）実験概要}

ここでは, 先送りモルタルの量を低減させるために, 先送り材の 種類・量および圧送方法を変えてポンプ圧送性の向上ならびにコン クリートの品質低下防止を踏まえて圧送実験を行った。この圧送実 験は，実長約 $70 \mathrm{~m}$ の配管を基準とし，ピストン式ポンプ車を用い た。圧送実験の要因は, 配管径, 先送り水の有無, 先送り材の種類・ 量, クリーナボールの有無扔よび圧送するコンクリートの品質を変 えてコンクリートのポンプ圧送性ならびに圧送したコンクリートの 品質を調べた。

(1) 実験日および場所

実 験 日; 平成 5 年 6 月 10 日

実験場所：群馬県三原興産敷地内

(2) 配管条件

圧送実験で行った配管状況図を図 2 に示す。ここでは, 配管径 100

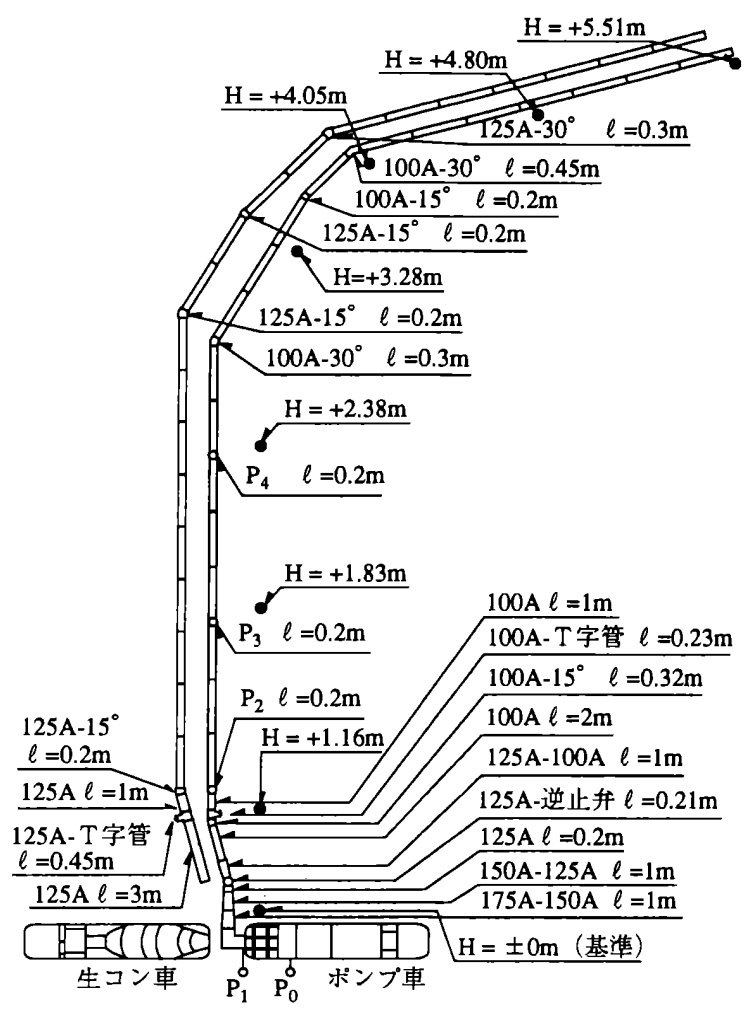

図 2 配管状況図 (平面図)

$\mathrm{A}$ 管および $125 \mathrm{~A}$ 管として, 実長約 $70 \mathrm{~m}$ (100 A 管の場合 67.65 $\mathrm{m}, 125 \mathrm{~A}$ 管の場合 $69.36 \mathrm{~m}$, 高低差約 $5.5 \mathrm{~m}$ )の途中に $30^{\circ}$ および $15^{\circ}$ テーパ管を設けた地上配管で緩斜面の上りの配管状態を基準と した。配管内は，圧送実験ごとに清掃を行い，ほほ同一状態になる ようにした。

(3) コンクリートポンプ車の仕様

圧送実験で使用したコンクリートポンプ車は，ピストン式（ $\mathrm{N}$ 社 製）で吐出量 $15 \sim 110 \mathrm{~m}^{3} / \mathrm{h}$ の一般的に用いられるものである。ま 
たこのポンプ車の仕椂概要は，コンクリートシリンダを 2 個有し， シリンダロ径×ストローク長が $210 \times 1,600 \mathrm{~mm}$ であり，標準時に おけるピストン前面圧が最大 $4.9 \mathrm{MPa}\left(50 \mathrm{kgf} / \mathrm{cm}^{2}\right)$ のものであ る。

\section{(4) 先送り材を変えた压送実験概要}

この先送り材の種類・量および圧送方法を変えた圧送実験概要を 表 1 に示す。压送実験は，大きく分けて5つのシリーズとし，配管 の種類, 先送り水の使用量, クリーナボールの有無, 先送り材の種 類・使用量扔よび压送したコンクリートの種類を変えた 14 種類の 圧送方法について行った。先送り材は，先送り材を用いない場合， セメントペースト, $1: 3$ モルタル $(\mathrm{W} / \mathrm{C}=42.1 \%), 1: 2$ モルタル $(\mathrm{W} / \mathrm{C}=34.2 \%)$ および特殊モルタルについて検討した。また，セメ ントペースト（W/C $=50 \%)$ はセメント 1 袋を簡易なハンドミキシ ング装置を用いて混練したものを圧送し，特殊モルタル8)はポンプ 用に調合したプレミクスタイプ（硅砂十増粘材十繊維含）のものを 簡易なハンドミキシング装置を用いて混練したものを圧送した。1： 3 モルタルならびに 1：2 モルタルは, 生コン工場において製造され たものである。クリーナボールは, 角スポンジ $(150 \times 150 \times 150 \mathrm{~mm})$ を用いた。これらの先送り材を用いて圧送したコンクリートの調合 を表 2 に示す。ここで, 呼び強度 ; $21 \mathrm{~N} / \mathrm{mm}^{2}\left(210 \mathrm{kgf} / \mathrm{cm}^{2}\right)$ のも のを標準調合とし，呼び強度： $27 \mathrm{~N} / \mathrm{mm}^{2}\left(270 \mathrm{kgf} / \mathrm{cm}^{2}\right)$ のものを 富調合として圧送した。

(5) 先送り材の圧送方法

本実験に扔ける先送り材の圧送方法は，施工指針と異なり，先送 り材をホッパーへ投入するのではなく，図 3 に示すようにテーパ管

表 1 先送り材の種類・量抢よび圧送方法を変えた圧送実験概要

\begin{tabular}{|c|c|c|c|c|c|}
\hline $\begin{array}{l}\text { 実験 } \\
\text { No. }\end{array}$ & 配管 & $\begin{array}{c}\text { 先送り水 } \\
\text { の使用量 } \\
(\ell)\end{array}$ & $\begin{array}{l}\text { クリーナ } \\
\text { の } \\
\text { 有無 }\end{array}$ & $\begin{array}{c}\text { 先送り材の種類 } \\
\text { および使用量 } \\
(\ell)\end{array}$ & $\begin{array}{l}\text { 圧送したコ } \\
\text { ンクリート } \\
\text { の種類 }\end{array}$ \\
\hline $\begin{array}{r}\mathrm{I}: 1 \mathrm{~A} \\
\vdots \\
\vdots \\
2 \mathrm{~A} \\
3 \mathrm{~A}\end{array}$ & $\begin{array}{l}100 \mathrm{~A} \\
100 \mathrm{~A} \\
125 \mathrm{~A} \\
100 \mathrm{~A}\end{array}$ & $\begin{array}{r}0 \\
10 \\
10 \\
10\end{array}$ & \begin{tabular}{l}
$x$ \\
$x$ \\
$\times$ \\
\hdashline
\end{tabular} & $\begin{array}{l}\text { なし } \\
\text { " } \\
\text { " }\end{array}$ & 標準調合 \\
\hline $\begin{array}{r}\text { II : } 4 \mathrm{~A} \\
\vdots \\
5 \mathrm{~A} \\
5 \mathrm{~B} \\
6 \mathrm{~A}\end{array}$ & $\begin{array}{l}100 \mathrm{~A} \\
100 \mathrm{~A} \\
125 \mathrm{~A} \\
100 \mathrm{~A}\end{array}$ & $\begin{array}{r}0 \\
10 \\
5 \\
5\end{array}$ & $\begin{array}{l}x \\
\times \\
\times \\
\stackrel{0}{0}\end{array}$ & $\begin{array}{c}\text { セメントペースト } 10 \ell \\
\text { " } \\
\text { " }\end{array}$ & \\
\hline $\begin{array}{r}\text { III } \\
7 \mathrm{~A} \\
\vdots \\
\\
8 \mathrm{~A} \\
\vdots \\
8 \mathrm{C} \\
9 \mathrm{~A}\end{array}$ & $\begin{array}{l}100 \mathrm{~A} \\
100 \mathrm{~A} \\
125 \mathrm{~A} \\
100 \mathrm{~A} \\
100 \mathrm{~A}\end{array}$ & $\begin{array}{l}0 \\
5 \\
5 \\
5 \\
5\end{array}$ & $\begin{array}{l}\times \\
\times \\
\times \\
\times \\
\times \\
0\end{array}$ & $\begin{array}{c}1: 3 \text { モルタル } 10 \ell \\
\text { " } \\
\text { " } \\
1: 2 \text { モルタル } 10 \ell \\
1: 3 \text { モルタル10 }\end{array}$ & \\
\hline $\begin{array}{r}\mathrm{IV} \\
\vdots 11 \mathrm{~A} \\
\vdots 11 \mathrm{~B} \\
\vdots 12 \mathrm{~A} \\
\end{array}$ & \begin{tabular}{l|}
$100 \mathrm{~A}$ \\
$100 \mathrm{~A}$ \\
$125 \mathrm{~A}$ \\
$100 \mathrm{~A}$ \\
\end{tabular} & $\begin{array}{l}0 \\
5 \\
5 \\
5\end{array}$ & $\begin{array}{l}x \\
x \\
x \\
0 \\
\end{array}$ & $\begin{array}{c}\text { 特殊モルタル10 } \ell \\
\text { " } \\
\text { " }\end{array}$ & \\
\hline $\begin{array}{r:}13 \mathrm{~A} \\
\vdots 14 \mathrm{~A}\end{array}$ & $\begin{array}{l}100 \mathrm{~A} \\
100 \mathrm{~A}\end{array}$ & $\begin{array}{l}0 \\
5\end{array}$ & $\begin{array}{l}x \\
x\end{array}$ & $\begin{array}{l}\text { なし } \\
\text { " }\end{array}$ & 富調合 \\
\hline
\end{tabular}

表 2 圧送したコンクリートの調合

\begin{tabular}{|c|c|c|c|c|c|c|c|c|c|c|c|}
\hline & & & & & & & & $E$ & 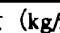 & & \\
\hline 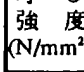 & & $\begin{array}{l}\bar{x} 5 / 7 \\
(\mathrm{~cm})\end{array}$ & $\begin{array}{l}\text { 空気 } \\
(\%)\end{array}$ & $(\%)$ & $\begin{array}{c}\mathbf{s} / \mathbf{a} \\
(\%)\end{array}$ & 水 & & & \begin{tabular}{|c|} 
粗省 \\
显通
\end{tabular} & & $\begin{array}{l}\text { 墄水 } \\
\text { 㓣 }\end{array}$ \\
\hline 21 & & $\sqrt{18}$ & 4.0 & 59.0 & 49.3 & 180 & & 73 & 364 & 6 & 0.7 \\
\hline & & & 0 & 9.7 & 17 & 81 & 1 & 23 & 164 & 362 & \\
\hline
\end{tabular}

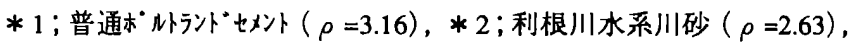

* 3 ; 粗骨材混合比 普通: 砕石 $=2: 3 \quad(\rho=2.63)$,

$* 4$; 普通砂利 $(\rho=2.64), * 5$; 両神産砕石 $(\rho=2.70)$

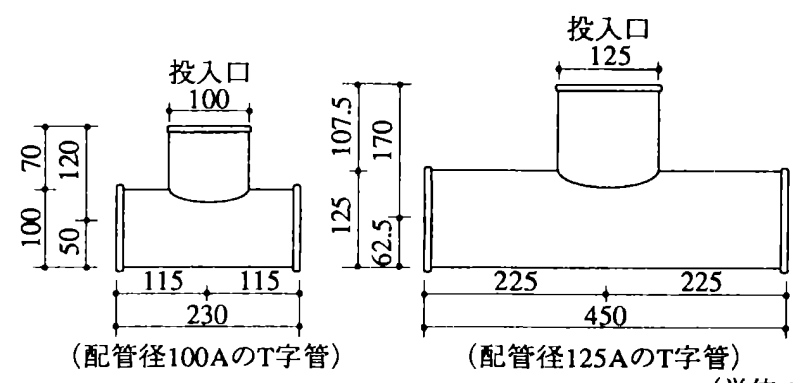

(単位：mm)

図３テーパ管の先に設けた T 字管による投入口

の先に T 字管の投入口を設け, 先送り水ならびに先送り材を給入 し，また，コンクリートはホッパーから投入して圧送した。この圧 送実験では，吐出量を低速 $20 \mathrm{~m}^{3} / \mathrm{h}$ 一定とし，圧送方法を変えて先 送り材をコンクリートとともに压送した。この T字管による投入口 を設ける圧送方法は, 先送りモルタルならびに先送り材の量を低減 させるために行ったものである。この中で，クリーナボールを用い た圧送方法は，角スポンジを先送り水の後に圧送した。

(6) 実験項目

先送り材の種類・量および圧送方法がコンクリートのポンプ圧送 性ならびに圧送したコンクリートの品質におよぼす影響を比較検討 するために, コンクリートの圧送距離(閉塞筒所の確認), 圧送した コンクリートの状態観察, 圧送先端より吐出した水 (残水) の量, 圧送したコンクリートのスランプ (閉塞した場合, その箇所より各 配管 1〜4 本目のスランプ）およびスランプ測定後の材齢 28 日珐縮 強度ならびに静弾性係数を測定した。また，図 2 に示す $\mathrm{P}_{0} \sim \mathrm{P}_{4}$ の 5 筒所(ポンプ車から $\mathrm{P}_{0}$; ポンプ車主油圧, $\mathrm{P}_{1}$; ピストン前面圧, $\mathrm{P}_{2}$; 吐出口から約 $8.5 \mathrm{~m}, \mathrm{P}_{3}$; 吐出口から約 $17.5 \mathrm{~m}, \mathrm{P}_{4}$; 吐出口から約 $26.7 \mathrm{~m})$ について圧力を測定し， $\mathrm{P}_{2} \sim \mathrm{P}_{4}$ の管内圧力はスチール製ダ イヤフラム式圧力計を用いて測定した。

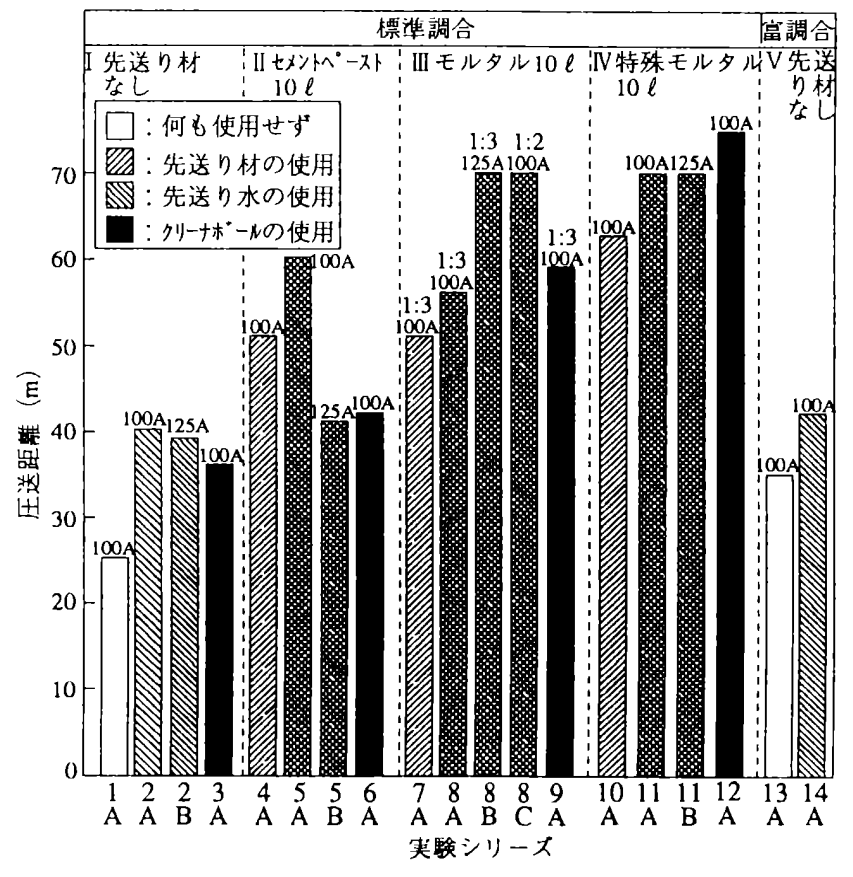

図 4 先送り材の種類・量抒よび圧送方法を変えた 実験シリーズと圧送距離の関係 
(2) 結果抢よび考察

(1) 先送り材の種類・量および圧送方法を変えたポンプ圧送性

先送り材の種類・量掞よび圧送方法を変えた実験シリーズと圧送 距離の関係を図 4 に示す。この結果から先送り水ならびに先送り材 を用いずに圧送した場合は，圧送距離は著しく短く, $25 \mathrm{~m}$ 程度で閉 塞を起こしており，これに先送り水を用いて圧送しても，何も用い ずに圧送した場合に比べ，若干圧送距離が長くなるが先送り材を用 いないと閉塞を起こしている。また，施工指針通りクリーナボール を用いて圧送した場合は, 先送り水㧍よび先送り材を用いて圧送し た場合に比べ圧送距離が短くなる傾向となっており，先送り材に特 殊モルタルを用いて圧送した場合以外は，閉塞を起こしている。こ れは，クリーナボールの大きさが配管内においてポンプ圧送性に悪 影響をおよぼしているためと考えられる。先送り水抢よび先送り材 を用いて $100 \mathrm{~A}$ 管に圧送した場合は, 先送り材の種類としてセメン トペースト，モルタル，特殊モルタルの順に圧送距離が長くなり， 特に 1:2 モルタルならびに特殊モルタルは，10 $\ell$ 程度で閉塞せず に圧送できることが確認された。先送り材に $1: 3$ モルタルを用い て圧送した場合は，配管径の違いにより圧送距離が長くなっている ことが確認された。この理由として, ポンプの吐出口 $\phi 210 \mathrm{~mm}$ から 各配管径へのテーパ管が影響を抢よぼしていると考えられる。圧送 したコンクリートの種類が単位セメント量の多い富調合を圧送した 場合は，先送り水を用いても圧送距離が著しく長くならず，圧送す るコンクリートの調合を考慮してもコンクリートのみで配管距離 $70 \mathrm{~m}$ 程度の圧送はできないと考えられる。

次に, 先送り材の種類・量および圧送方法を変えた実験シリーズ における压力測定結果を表 3 に示す。ポンプ主油圧, ピストン前面

表 3 先送り材の種類・量および圧送方法を変えた 実験シリーズに扔ける圧力測定結果

\begin{tabular}{|c|c|c|c|c|c|c|}
\hline \multirow{2}{*}{\multicolumn{2}{|c|}{$\begin{array}{c}\text { 実 験 } \\
\text { No. }\end{array}$}} & \multirow{2}{*}{$\begin{array}{c}\text { ボンプ主油压 } \\
\mathrm{P}_{0} \\
\end{array}$} & \multirow{2}{*}{ 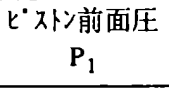 } & \multicolumn{3}{|c|}{ 管内压力 } \\
\hline & & & & $\mathrm{P}_{2}$ & \multirow{2}{*}{$\frac{P_{3}}{0.00}$} & \multirow{2}{*}{$\frac{P_{4}}{0.00}$} \\
\hline I & $1 \mathrm{~A}$ & 17.96 & 4.08 & 2.96 & & \\
\hline & $2 \mathrm{~A}$ & 8.99 & 2.04 & 1.59 & 1.45 & 1.83 \\
\hline & 2B & 6.54 & 1.48 & - & - & - \\
\hline & $3 \mathrm{~A}$ & 15.93 & 3.61 & 3.12 & 3.10 & 3.67 \\
\hline \multirow[t]{4}{*}{ II } & $4 \mathrm{~A}$ & 8.99 & 2.04 & 1.56 & 1.31 & 1.16 \\
\hline & $5 A$ & 21.24 & 4.81 & 4.28 & 3.94 & 3.84 \\
\hline & $5 B$ & 15.66 & 3.55 & - & - & - \\
\hline & $6 \mathrm{~A}$ & 20.88 & 4.73 & 4.37 & 4.51 & 4.17 \\
\hline \multirow{5}{*}{ III } & $7 \mathrm{~A}$ & 20.88 & 4.73 & 3.81 & 3.67 & 3.59 \\
\hline & $8 \mathrm{~A}$ & 12.45 & 2.82 & 2.20 & 2.25 & 1.93 \\
\hline & $8 B$ & 4.02 & 0.91 & - & - & - \\
\hline & $8 \mathrm{C}$ & 4.82 & 1.09 & 0.57 & 0.47 & 0.37 \\
\hline & $9 \mathrm{~A}$ & 14.46 & 3.27 & 2.38 & 2.54 & 1.97 \\
\hline \multirow[t]{4}{*}{ IV } & $10 \mathrm{~A}$ & 20.08 & 4.56 & 4.29 & 4.04 & 4.32 \\
\hline & $11 \mathrm{~A}$ & 5.63 & 1.27 & 0.67 & 0.56 & 0.46 \\
\hline & $11 \mathrm{~B}$ & 4.82 & 1.10 & - & - & - \\
\hline & $12 \mathrm{~A}$ & 5.22 & 1.19 & 0.57 & 0.47 & 0.37 \\
\hline \multirow[t]{2}{*}{$\mathrm{V}$} & $13 \mathrm{~A}$ & 19.28 & 4.37 & 3.47 & 3.57 & 0.00 \\
\hline & $14 \mathrm{~A}$ & 13.65 & 3.10 & 2.44 & 2.20 & 2.48 \\
\hline
\end{tabular}

(単位: $\mathrm{MPa}$ )

圧抢よび管内圧力は, 先送り材の種類・量および圧送方法により同 様な大小関係を示しており，圧送距離が長くなるにつれて小さくな

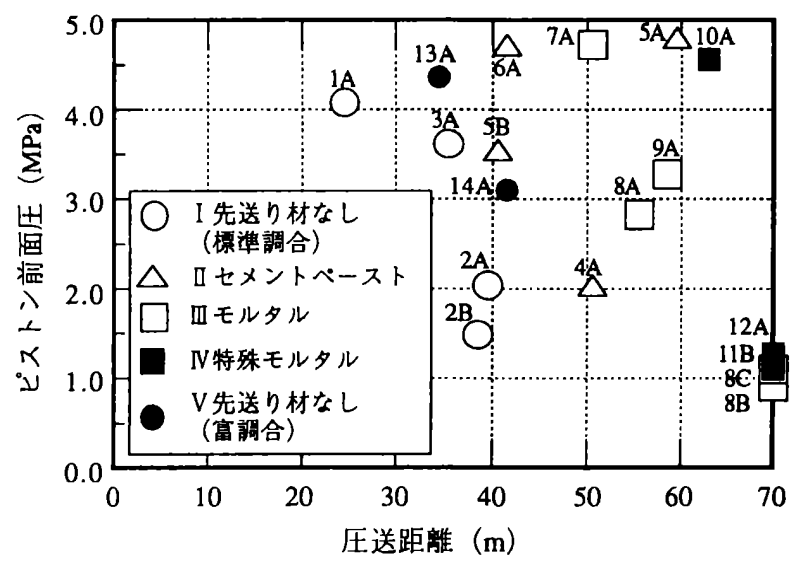

図 5 圧送距離とピストン前面圧の関係

る傾向を示していた。また, $\mathrm{P}_{2} \sim \mathrm{P}_{3}$ 間の圧送距離約 $9 \mathrm{~m}$ における圧 力損失は, $0.1 \sim 0.3 \mathrm{MPa}\left(1 \sim 3 \mathrm{kgf} / \mathrm{cm}^{2}\right)$ 程度となっており $\mathrm{P}_{3} \sim \mathrm{P}_{4}$ 間の圧送距離約 $9 \mathrm{~m}$ における圧力損失も同様な結果であった。この 中で，先送り材・量および圧送方法を変えた実験シリーズにおける 圧送距離とピストン前面圧の関係を図 5 に示す。先送り材の種類・ 量㧍よび圧送方法を変えた実験シリーズのピストン前面圧は，先送 り材の種類・量および圧送方法により異なり，閉塞を起こさない場 合, ピストン前面圧が低くなることがわかる。この中で, $10 \mathrm{~A}$ のよ うに圧送距離が長い場合でも閉塞を起こすとピストン前面圧は高く なっている。閉塞を起さない良好な圧送方法は，ポンプの性能にお ける最大ピストン前面圧 $4.9 \mathrm{MPa}\left(50 \mathrm{kgf} / \mathrm{cm}^{2}\right)$ に対して約 $30 \%$ (1.47 MPa：15 kgf $/ \mathrm{cm}^{2}$ ) 程度以下のピストン前面圧で圧送できれ ば良好な圧送と考えられる。

(2) 先送り材の種類・量抢よび圧送方法を変えて圧送したコンクリー 卜の品質

先送り材の種類・量および圧送方法を変えた実験シリーズにおけ

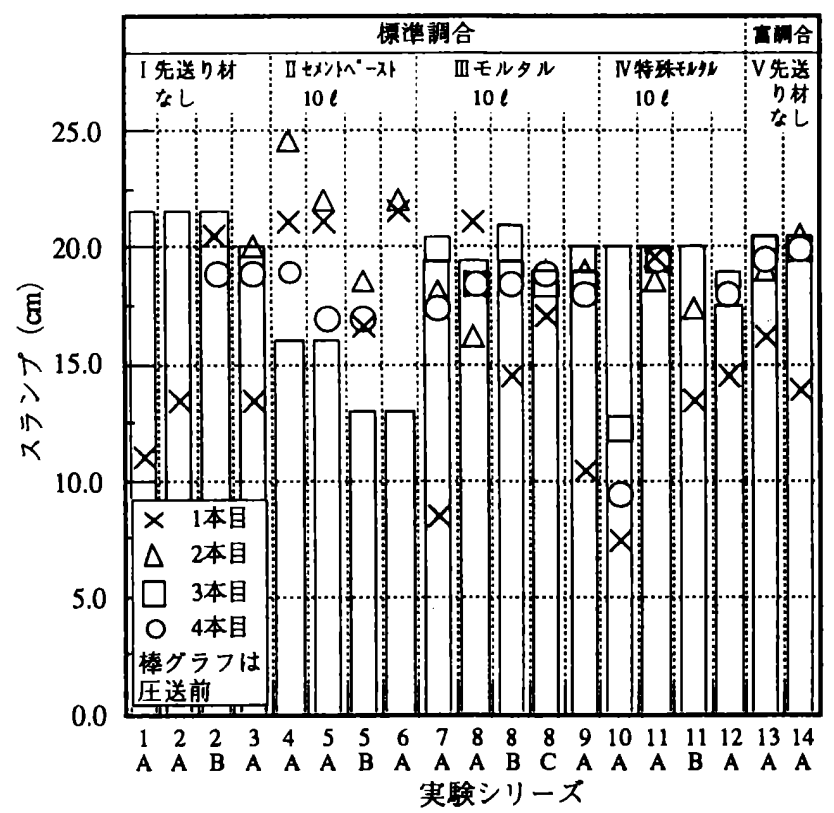

図 6 先送り材の種類・量および圧送方法を変えた 実験シリーズとスランプの関係 
る圧送距離とスランプの関係を図 6 に示す。先送り材の種類・量お よび圧送方法を変えた実験シリーズにおけるスランプは, 閉塞を起 こした場右，その先端部分のスランプが管理值内に入らず，目視に よるコンクリートの状態観察も先送り水を用いずに圧送した場合, ほとんどがばさばさな状態であった。また，先送り水を用いて圧送 した場合, ほとんどが分離状態であり，さらにクリーナボールを用 いて圧送しても影響は見られなかった。しかし，先送り材を用いて 圧送した場合，スランプも 2 本目から管理值内に入る傾向にあり, コンクリートの状態観察も 2 本目から良好な状態になっていた。こ のことから考えると先端部分加ら 1 本目のコンクリートは先送り水 を用いると分離を起こし，先送り水を用いないとばさばさな状態と なり，また，先送り材を用いたとしても先端部分から 1 本目のコン クリートの品質は良好でないため, 先送り材を用いても先端部分か ら 1 本目のコンクリート（約 $25 \ell$ ）は，廃棄する必要があると考え られる。

次に, 先送り材の種類・量および圧送方法を変えた実験シリーズ に抢ける圧送距離と材齢 28 日圧縮強度の関係を図 7 に示す。先送

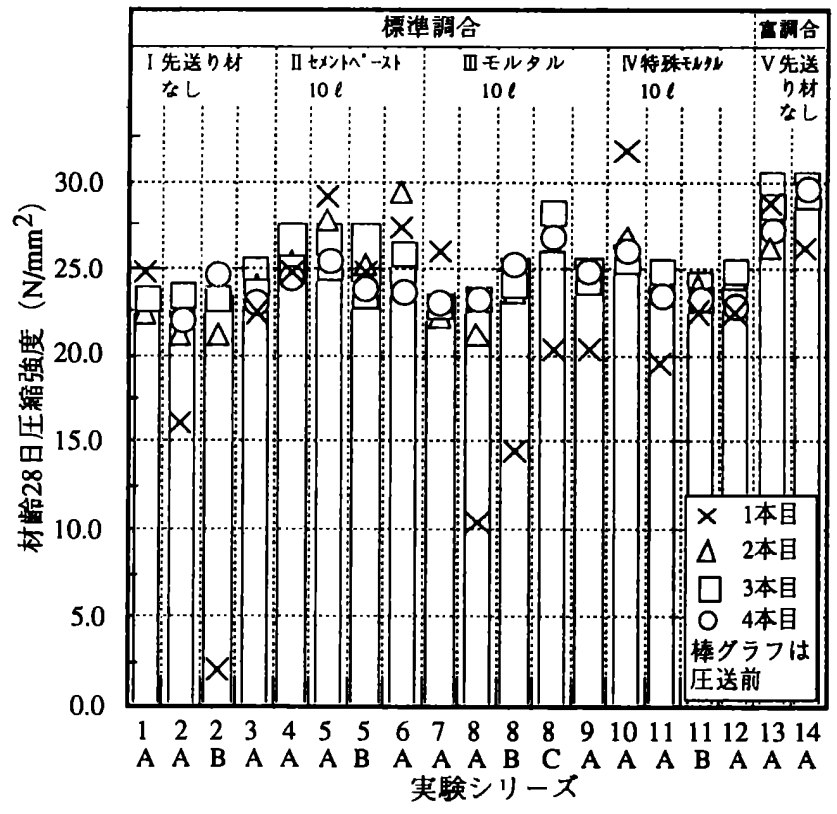

図 7 先送り材の種類・量および圧送方法を変えた 実験シリーズと材齢 28 日圧縮強度の関係

り材の種類・量および圧送方法を変えた実験シリーズにおける材齢 28 日圧縮強度は, 先端部分から 1 本目のコンクリートではほとんど の場合圧送前の圧縮強度に比べ小さくなっている傾向（圧送前の圧 縮強度比に換算すると 0.08 1.20) が確認された。この中で, 先送り 水を用い圧送した場合などの $2 \mathrm{~B}, 8 \mathrm{~A}$ および $8 \mathrm{~B}$ は, 圧送前に比べ 著しく小さくなっていた。また，ポンプ圧送性が良好であった先送 り水と $1: 2$ モルタルおよび特殊モルタルを圧送した場合の先端部 分から 1 本目のコンクリートの圧縮強度は，圧送前とほほ同等（圧 送前の圧縮強度比に換算すると0.79〜1.20)であった。しかし， 2 本目以降の圧縮強度は, 先送り材の種類・量および圧送方法に関わ らずばらつきも小さく，圧送前の圧縮強度とほぼ同等程度（圧送前 の圧縮強度比に換算すると 0.91 1.16) となり圧縮強度の面からも

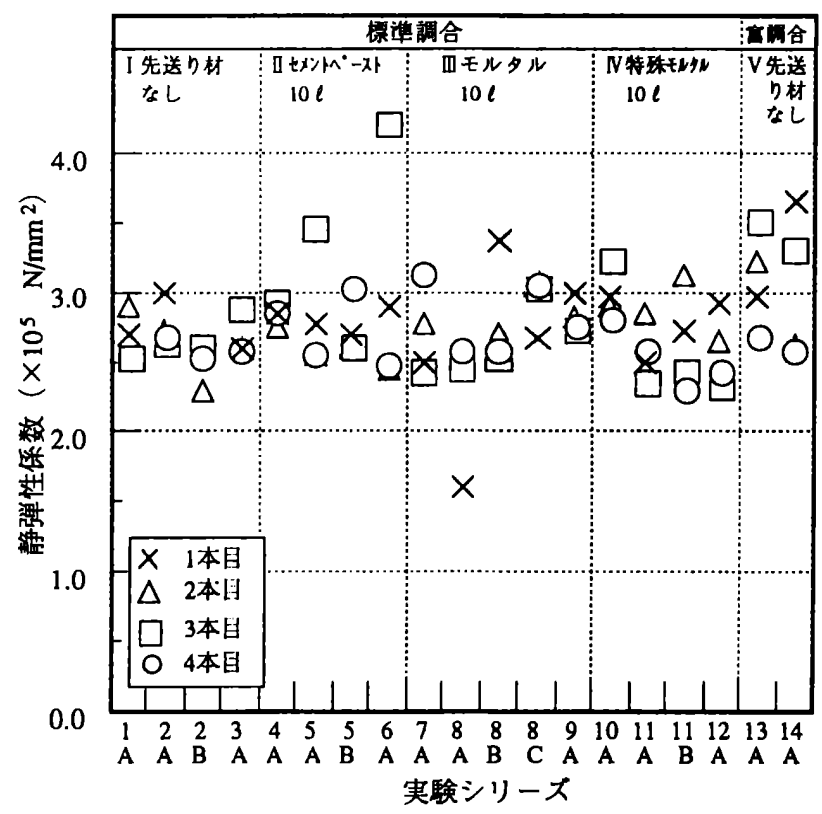

図 8 先送り材の種類・量扔よび玨送方法を変えた 実験シリーズと静弾性係数の関係

先端部分から 1 本目のコンクリートは, 問題があり廃棄すべきと考 えられる。

次に, 先送り材の種類・量および圧送方法を変えた実験シリーズ における圧送距離と静弾性係数との関係を図 8 に示す。静弾性係数 は，スランプおよび圧縮強度に比べばらつきが小さく比較的安定し た結果となった。また，スランプならびに圧縮強度とは異なり，先 端部から 1 本目のコンクリートが小さくなる傾向ではなかった。

(3) まとめ

先送り材の種類・量および圧送方法を変えた圧送実験を行い，先 送り材の評価は表 4 に示すようになり，圧送方法を踏まえると次の ことがいえる。

表 4 先送り材の評価

\begin{tabular}{|c|c|c|c|c|c|c|c|}
\hline & 洖り材 & & ペー & & タル & 特殊 & 富調合 \\
\hline 配管径 & & なと & スト & $1: 3$ & $1: 2$ & タル & リート \\
\hline なし & $100 \mathrm{~A}$ & $x$ & $\Delta$ & $\Delta$ & $0^{*}$ & $\mathrm{O}$ & $x$ \\
\hline a $2 n$ & $100 \mathrm{~A}$ & $x$ & $\Delta$ & 0 & (0) & (0) & $\Delta$ \\
\hline 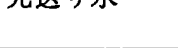 & $125 \mathrm{~A}$ & $\Delta$ & $\Delta$ & 0 & (0) * & (1) & $\Delta^{*}$ \\
\hline $\begin{array}{l}\text { 先送り水+ } \\
\text { クリーナー }\end{array}$ & $100 \mathrm{~A}$ & $x$ & $\Delta$ & 0 & $0^{*}$ & 0 & $x^{*}$ \\
\hline
\end{tabular}

○：良，○：やや良， $\Delta$ : やや不可，×：不可（*印は推定による）

(a) 先送り材は，ホッパーからの投入でなくテーパ管の先に T 字 管の投入口を設けて圧送すると先送り材の量を低減できる。

(b) 先送り材に $1: 2$ モルタルおよび特殊モルタルなどの高品質 のモルタルを用いることから先送り材の量を低減できる。

(c) 先送り材の種類に関わらず先端部分から 1 本目のコンクリー

卜 $($ 約 $25 \ell$ l) は，廃棄する必要があると考えられる。 


\section{5 先送りモルタルの低減}

先送りモルタルを低減するための圧送方法は，次の方法があげら れる。

(1) 先送りモルタルを全く用いない圧送方法

アンケート調査結果の中から先送りモルタルを全く用いない場合 として, 主に配管距離が短い場合, ブームポンプ車の場合, 圧送す るコンクリートの調合による場合などがあげられ，圧送施工技能士 の技術ならびに経験により先送りモルタルを全く用いないで圧送す る。しかし，閉塞の危険性が多分にあるため，充分な注意を要する。

(2) 先送り材の種類および圧送方法を変えた圧送方法

先送り材は, ホッパーからの投入ではなくテーパ管の先に T字管 の投入口を設けて圧送し先送り材の種類として $1: 2$ モルタルおよ び特殊モルタル（プレミックスタイプ）などの高品質なモルタルを 用いて圧送する。

本報告中に提案した圧送方法により，先送りモルタルの低減率は 次のように推測される。アンケート調查によると先送りモルタルは 約 90\%以上が使用されている。また，その調合は，1:3 モルタルが 約 $80 \%$ であり，1回の使用量は， $0.5 \mathrm{~m}^{3}$ と $1.0 \mathrm{~m}^{3}$ が最も多いこと から, 年間の先送りモルタルの消費量 $(V)$ を推定してみると次式で 計算される。

条件 $a$ : 先送りモルタルの 1 回の消費量: $0.5 \sim 1.0 \mathrm{~m}^{3}$ $b$ : コンクリートポンプ車大手 4 社過去の 10 年間の台数 4870 台 $\fallingdotseq 5000$ 台 c: ポンプ車の稼働数 ポンプ車 1 台当たり月 13〜26回○20回 年 $20 \times 12=240$ 回

$\alpha$ :全先送り材に対するモルタルの使用割合

$\therefore \quad V=[a(b \times c)] \times a$

$=[0.5 \sim 1.0(5,000 \times 240)] \times 0.76$

$=\left[600,000 \sim 1,200,000 \mathrm{~m}^{3}\right] \times 0.76$

$=45.6 \sim 91.2$ 万 $\mathrm{m}^{3}$

すなわち年間のモルタルの消費量としては，45万 $\mathrm{m}^{3}$ から 90 万 $\mathrm{m}^{3}$ が消費されていることになる。压送方法も踏まえ $1: 3$ モル夕ル に比較して, 1:2 モルタルは 1 2 倍程度, 特殊モルタルで 2 3 倍 程度の効果が見いだされた。したがって, 先送りモルタルに $1: 2$ モ

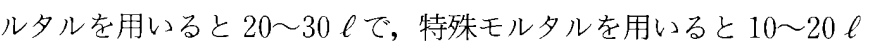

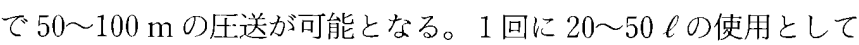

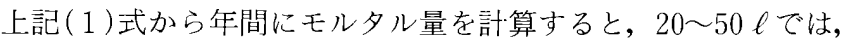
$24,000 \mathrm{~m}^{3} \sim 60,000 \mathrm{~m}^{3}$ となり $1 / 15 \sim 1 / 20$ の低減率となる。

\section{6 まとめ}

本研究を行い，先送り材の種類・量および圧送方法を変えること から現状の先送りモルタルの低減に方向性を見いだした。この先送
りモルタルの低減は，身体となるコンクリートの品質，資源の節約 およびリサイクルの観点に大きな意義をもたらすと確信する。また， 本実験では水平管のみの $70 \mathrm{~m}$ の圧送実験であったが，今後はブー 厶車による圧送, 配管条件, 垂直管, 天候, 気温㧍よびコンクリー トの種類などを含めた検討を行い, 先送りモルタルの適切な圧送方 法抢よび廃棄量の低減をさらに検討していきたい。

\section{謝 辞}

本研究を行うに当たり, 日本建築学会コンクリートポンプ小委員 会の方々から゙意見を頂き，全国コンクリート圧送事業団体連合会 および(社)建築業協会の方々にアンケートを回答して頂いた。また， このアンケート調查は，廃棄物の抑制という観点から(財)国土開発 技術研究センター「建設副産物の発生抑制·再利用技術の開発」(委 員長 東京大学友澤教授)の一部に扔いて行ったものである。実験を 行うに当たり群馬県生コン中央協会，全国コンクリート圧送事業団 体連合会技術委員会，地頭園氏ならびに今泉氏（三菱マテリアルセ メント研究所), 吉川氏 (新潟建機営業推進本部), 宮池氏 (足利工業 大学大学院）の多数の方々にご協力を得た。ここに付記し，謝意を 表する。

\section{参考文献}

1）森永繁：『コンクリートポンプ工法施工指針・同解説』改訂の要 点, セメント・コンクリート, No. 566, pp. 68〜 72, 1994

2）「コンクリートポンプ工法施工指針・同解説」, 日本建築学会, 1994

3）森永繁, 野荁勝久, 成田一徳, 妻鳥淳二：コンクリートポンプ工 法に抢ける先送りモルタルの品質, 日本建築学会大会学術講演 梗概集 A, pp. 381〜382, 1979.9

4）長尾信夫, 小池茂, 毛見虎雄, 中田善久：コンクリートポンプ工 法における先送り潤滑材に関する研究々の 1 圧送業に扔け る先送り潤滑材の実態調査, 日本建築学会関東支部研究報告集 構造系, 1993.3

5）毛見虎雄, 中田善久：コンクリートポンプ工法における先送り 潤滑材に関する研究 その 1 研究主旨および建設業に打ける 先送り潤滑材の使用状況実態調査，日本建築学会大会学術講演 梗概集 A, pp. 253〜254, 1994.9

6）長尾信夫, 毛見虎雄, 中田善久, 藤井和俊, 小池茂：コンクリート ポンプ工法に扔ける先送り潤滑材に関する研究 その 2 各種 潤滑材の圧送実験計画とその適応性, 日本建築学会大会学術講 演梗概集 A, pp. 255〜256, 1994.9

7）小池茂, 毛見虎雄, 中田善久, 地頭園博, 長尾信夫：コンクリート ポンプ工法に抢ける先送り潤滑材に関する研究 その 3 各種 潤滑材の圧送実験結果，日本建築学会大会学術講演梗概集 A, pp. $257 \sim 258,1994.9$

8）今泉裕隆, 毛見虎雄, 藤井和俊, 地頭園博: ポンプ圧送用先送り 特殊モルタルに関する研究，日本建築学会大会学術講演梗概集 A, pp. 251 252, 1994.9

[1995 年 6 月 15 日原稿受理 1995 年 8 月 25 日採用決定］ 